\title{
Raising Questions and Finding Answers: Money Laundering in Light of Three Theories
}

\author{
Iv Rokaj \\ Lecturer at the Faculty of Law, University of Tirana. LL.M at University at Buffalo, The State University of New York \\ E-mail: iv_rokaj@yahoo.com
}

\section{Doi:10.5901/ajis.2015.v4n3p285}

\begin{abstract}
Globalization and technology have raised a complete new prospective of trade and finance flows across the globe. Money laundering is one of the biggest obstacles for creating a safe and effective operating international financial system. It is considered now the third largest "business" in the word and has very deep political and economic implications. Unfortunately money laundering is more then only that, and the reasons why, would be modestly explored by this article. This article approach to money laundering will be from a different prospective, and will try to go to the core of the theoretical understanding, for then trying to explore and give suggestions for the practical issues as they have been argued by many scholars, legal and financial experts. This article will try to understand better money laundering by addressing common aspects with other three theories, that among the others, I find particularly interesting because they share common or diametrically opposite elements. The legislator in money laundering was worried by criminalizing this offense not only because of the moral blameworthiness or the harm caused by looking in the past, for what it relates to the underlying offense and its danger, but mostly for the future fear of generating criminality and further wrongful conducts and harm. Preventing further criminality meets perfectly with all consequentialist reasons of imposing punishment. This view of money laundering as a "harm generator" or "wrongness generator", is the most convincing about the real reasons of criminalization.
\end{abstract}

Keywords: Money Laundering Criminalization, Parasitic Crime, Inchoate Offense, Blackmail Paradox, Criminality Generator

\section{Introduction}

I believe that the wrongfulness of money laundering in itself without trying to associate this offense with something else is one of the most difficult questions. I chose to answer this question deliberately, without hiding in practical issues regarding this offense, making clear from the beginning that this approach does not underestimate the practical discussions, instead tries to build a comprehensive theoretical understanding of the deep reasons of why money laundering is morally wrong or does create harm to society, and consequently reinforce the reasoning of criminalizing this conduct.

"Hart says, that retributivism responds to three questions. What kind of behavior can be punished? How severely? What justifies punishment? The simple model of retributivism subsequently means that a person can be punished only when he did voluntarily something morally wrong, that this punishment must be in some way equal, or equivalent to the atrocity of his crime and also that justification of punishment consists in the fact that punishment is a negative response to the offender doing something morally wrong", (Hart: 2008)

On the other hand, under a consequentialist theory a conduct, a behavior or a rule is morally right at the moment, when the anticipated consequences are better than all alternatives that are available, including a totally passive attitude (Sobek: 2011). Under a utilitarian view punishment is morally justified when the general utility is greater than any available consequence.

This article will try to understand better money laundering by addressing common aspects with other three theories, that among the others, I find particularly interesting because they share common or diametrically opposite elements.

Two different premises should be taken in consideration before trying to illustrate the theories. The first premise to take in consideration is that money laundering as described and criminalized by statutes, is a self-standing, independent offense.

The second premise to take into consideration, to better understand the way that the follow theories are constructed, is by dividing money laundering in two separate distinctive layers. The first layer is the illegal, unlawful offense that generates the money, or differently the source which produces the funds to be laundered. The second layer 
includes the process of laundering in itself, everything described as per techniques and tools to convert the illegal funds into seemingly clean legal funds. If we can explain by meaning of an example, the most common one is: the underlying offense that produces the funds by selling drugs and receiving cash as payment, constitutes the first layer. The second layer, the money laundering offense includes, as a simple example, opening a travel agency and producing fake invoices in addition to the real ones for the clients, so that the amount declared to the IRS, as a profit from this business, includes the real money profited from the clients and the illegal funds profited by non-existing clients, that in this case is the drug provided cash. All the money profited by this business, is after tax declaration, a "legal" laundered fund that can be invested or reused in any form. The method used is basically comparative in itself, even though the novelty of discussing money laundering criminalization in this view, creates the possibility not only to address new theoretical questions in money laundering, but mostly to use the comparative method of the three novel, but the same time old theories to better understand and answer money laundering criminalization issues.

\section{Money Laundering in light of three theories}

\subsection{Money laundering as a parasitic crime}

The first theory that I want to explore is by addressing money laundering as a parasitic crime. It is useful first to explain, although it is common knowledge, the meaning of the term "parasitic", as related to or characteristic of parasites. Parasites means an organism that lives on, or in an organism of another species, known as the host, from which it obtains nutriment.

Similarly, in money laundering cases, taking in consideration the promises made before, we can argue that there is a "host offense" 2 and a "parasitic offense 3 ". Why I believe that money laundering, even though described as an independent and free standing offense by statutes and courts, in reality is so deeply interrelated and interconnected with the underlying "host offense", in terms of theoretically understanding?

Thinking about money laundering as a whole independent crime makes no sense to answer the main question, of what is morally wrong with it and consequently reinforcing or not, the reasons of criminalizing this conduct. This question raises basically under the retributivist theory ${ }^{4}$ of comprehending what is morally wrong with a conduct to constrain the government to impose punishment. Is it morally wrong to do a bank transaction, to open a business, to write a check or a money order or simple to swipe the credit card in a machine? Does moral blameworthiness stretch to simple crossing the border with an amount of money in your pocket, like every other citizen? This paper is not written to answer the question, whether is it constitutionally right and how the government is restricting our rights to have property, money and freely move without restrains? Answering this question is futile. Every government imposes criminal restrictions, most of them named malum prohibitum offenses, to regulate social and economic life in general. This is part of our social contract ${ }^{5}$ with the State. Hart argues that "if a group of people devotes to a certain common activities according to certain rules, then the

\footnotetext{
1 http://dictionary.reference.com/browse/parasite.

2 The primary meaning of the world "host" is the organism that provide food and services for the surviving of the parasite. In this context the world host, is the offense that generates the illegal funds to be launder.

${ }^{3}$ New terminology to explain a new category of crimes, such as money laundering etc.

${ }^{4}$ Literature sometimes distinguishes between moral and legal retributivism because while moral retributivism focuses only on mala in se and not on mala prohibitum. Moral retributivism different from legal retributivism because it focuses on grounds of punishment that can be identified independently of the state's decision to criminalize certain activities. Consequently, moral retributivism does not need to justify many of the behaviors that are currently part of a criminal law such as financial crimes.

5 Social contract theory, nearly as old as philosophy itself, is the view that persons' moral and/or political obligations are dependent upon a contract or agreement among them to form the society in which they live. Socrates uses something quite like a social contract argument to explain to Crito why he must remain in prison and accept the death penalty. However, social contract theory is rightly associated with modern moral and political theory and is given its first full exposition and defense by Thomas Hobbes. After Hobbes, John Locke and Jean-Jacques Rousseau are the best known proponents of this enormously influential theory, which has been one of the most dominant theories within moral and political theory throughout the history of the modern West. In the twentieth century, moral and political theory regained philosophical momentum as a result of John Rawls' Kantian version of social contract theory, and was followed by new analyses of the subject by David Gauthier and others. More recently, philosophers from different perspectives have offered new criticisms of social contract theory. In particular, feminists and race-conscious philosophers have argued that social contract theory is at least an incomplete picture of our moral and political lives, and may in fact camouflage some of the ways in which the contract is itself parasitical upon the subjugations of classes of persons. Internet Encyclopedia of Philosophy.
} 
people, who submitted to the rules, restricted their own freedom and they have a right to request the same from those, who benefit from their self-restriction."(Hart:1955).

One of the real questions is why money laundering, as a malum prohibitum crime is punished as a malum per se crime? There has to be a strong moral reason for imposing punishment harshly, most of the time even more harshly then the host offense that creates the proceeds or provides the nutriment 6 .

I believe, it is precisely the underlying offense, the illegal unlawful funds generator, the one that transfers all the moral blameworthiness of that conduct in the parasitic money laundering offense. The nutriment necessary for a parasitic crime to survive, is offered continuously by the host offense. This nutriment that it is vital as in nature, in this case is the illegal proceed, the dirty money, as it is well known in the slang of law enforcements authorities. It is impossible to think about money laundering when the illegal derived money is not provided because money is the core element of the offense, the illegal nutriment absorbed from the host offense that generates criminal proceeds.

If we discuss money laundering criminalization from a utilitarian harm principle position, we can argue that money laundering act in itself, by simply doing a bank transaction, opening a business, writing a check or a money order, or swiping the credit card in a machine, does not provide any harm to citizen or society. The harm caused seems related more with the underlying host offense, whichever it might be. This second consequentialist approach is more puzzling because indirectly introduces into the equation account, the future possible harm stimulated by money laundering as a criminal sponsor and incentive to implement criminality. General and specific deterrence and incapacitation have a fundamental role in preventing further criminality to take place. This consequentialist view that may suggest imposing punishment for money laundering, is correct under the supposal that new criminality will be generated. The specific deterrence requirements are met when good consequences are produced.

This paper length does not allow to take in consideration and better analyze the international aspect of money laundering, as a valid reason to explain the anomaly of a first impact malum prohibitum crime that is punished as a malum per se crime, but I admit that the fact that there is an international concern and a transnational implication, may affect the answer.

\subsection{Trying to explaining money laundering by using the paradox of blackmail}

The paradox of blackmail has puzzled scholars and law professor for long time. Blackmail paradox can simply be described as the follow statement made by Mitchell N. Berman (Berman: 1988): I am legally free to reveal embarrassing information about you. Generally speaking, I am also free to negotiate payment to refrain from exercising a legal right. But if combined the two-offering to remain silent for a fee-l am guilty of a felony: blackmail. What is clear now, is that we have different views carried out by various important names in criminal law field, but no one has found the ultimate response, taking in consideration that one may exist. What is the connection between money laundering and blackmail? As we discussed and previously agreed, thinking about money laundering as a process made by two independent layers, blackmail is also made by to separate layers, as Breman and other scholars, like Feinberg ${ }^{7}$, before him has stated.

Joel Feinberg, one of the first scholars to raise this question (Feinberg: 1988), similarly questioned himself about the fact that blackmail is the result of the combination of two ways of behaving which often both lawful if taken individually, but unlawful once they are connected. In the blackmail case, the first layer is the two separate behaviors and the second layer is represented by the paradoxical fact that their merge creates something illegal.

Concretely, blackmail paradox has a first legal lawful layer, constituted by the fact that everyone is legally free to reveal embarrassing information, or free to negotiate payment to refrain from exercising a legal right. The second layer in this case is constituted by the merging of both those rights by offering to remain silent for a fee.

In money laundering is the opposite, the unlawful layer is the first one, the one that generates the illegal proceeds. Taking in consideration the paradox of blackmail, when the offer transforms in a threat and consequently becomes an offense, it is clear that the paradox in money laundering does not exist, because the second layer is constituted by perfectly legal behaviors as mentioned before, doing a bank transaction, opening a business, writing a check or a money order, or simple swiping the credit card in a machine, so criminalization should come from somewhere else.

There is only one simple answer ruled by the law of exclusion, and in this case directs us to the first layer. The

\footnotetext{
6 In this case the nutriment is the illegal proceeds.

${ }^{7} \mathrm{He}$ is known for his work in the fields of ethics, action theory, philosophy of law, and political philosophy as well as individual rights and the authority of the state. Feinberg was one of the most influential figures in American jurisprudence of the last fifty years.
} 
wrongfulness and the harm produced by the first layer, the underling offense that produced the illegal funds in money laundering "poisons" the second one. This is maybe why money laundering although treated as independent, carries out the wrongfulness, the harm or the moral blameworthiness of the first layer, whichever offense that might be. That is why no paradox is found when money laundering is criminalized, although both offense share a similar structure. This fact is puzzling because even though, and I clearly agree that no paradox is present, the theoretical reasons behind money laundering criminalization need to be discussed, first to better understand the criminalization of this offense, and then rely on guidance to solve legislative and practical implications.

Also, I believe that discussing the paradox of blackmail and money laundering, viewed in this prospective as opposite to each other, will not only raise questions regarding money laundering and its theoretically source of imposing punishment, but also will help to think about blackmail in a different prospective. Criminal law requires us to be open minded and rethink about different institutes of law or specific offense, by different points of view. With this questions in mind, I will start now discussing money laundering as an inchoate offense or an inchoate process.

\subsection{Can money laundering be an inchoate offense? Or it is an inchoate process?}

An inchoate offense is usually and generally described under the category of attempts. The simplest, but most acceptable definition of attempts is that "criminal liability attaches whenever someone tries to commit an offense but fails to successfully consummate it,"(Chiesa: 2014) or as "failures by definition, and thus they do not produce the harm of the completed crime. However, attempts themselves have their own harmful effects on citizens' ability to lead peaceful and secure lives."(Hasna:2012).

Professor Yaffe, at the very beginning of his article Criminal Attempts argues that " $[$ ] 0 good reason, attempts to commit crimes are themselves crimes in every mature legal system. A bungled robbery, a missed shot, a beating that fails to kill despite the perpetrator's best effort, a would-be rape fought off by the intended victim, a smuggling stopped at the border, and many more failed efforts besides possess the marks of wrongful conduct to which the state should respond with criminal penalties."(Yaffe:2014).

What is that really connects this doctrine and money laundering? We can think about several issues that can be explored by both.

First, attempts are criminalized because as money laundering they have a strange and anomalous relations with another offense, the one that we agreed to call the underlying offense. Criminal attempts will not exist if we do not have an offense, which result is willing to be achieved. There is no attempt to rob a bank if there would be no robbery offense. There is no attempted murder when there is no murder offense. Attempts are inextricably related with the offense that they tend to achieve.

Money laundering is by the same token inextricably related with the underlying offense that generates the illegal proceeds. Without that offense, any supposed money laundering would be a perfect legal activity, which punishment would be impossible morally and legally.

Thinking in view of this prospective, the fact that criminal attempts are being criminalized and punishment is imposed legally and independently from the offense that was intended, by treating attempts theoretically related to that offense, in the same way money laundering is criminalized by statutes independently from the offense that generated the illegal proceeds. By applying this logic, some of the theoretical reason of imposing punishment for attempts, should apply to money laundering. Maybe a reason is, as Prof. Hasnas describes, attempts' own harm to citizens.

The only missing part is the fact that no authors has devoted the necessary attention to the relation that money laundering has without any doubt with that offense. This article takes in examination extensively that prospective, as very important.

Second, thinking in terms of preparation to commit a crime. Criminal attempts are per definition a phase during the course of the commission of the crime that tends to achieve the result, but for different reasons not related to the actor, the result cannot be obtained. Criminals are punished mostly because they have the intent to commit a certain criminal act, regardless the result. Similarly in money laundering, after the process of laundering the illegal proceeds, new criminality tends to be created, as a course in the commission of a new crime. Money laundering in this case serves as an incentive of promoting new criminality, by using the illegal proceeds previously laundered. Illegal derived money are more flexible to be used and to promote new criminality or new tools and techniques for further laundering processes. This is a way of thinking of money laundering mostly by looking forward to the future and not only to the previous offense that generated the illegal proceeds.

Consequentialism imposes punishment on the basis of this view, by looking forward and foreseeing the future acts, 
because of the fact that at the end, better consequences will be achieved because of the imposition of punishment.

Third, viewing money laundering and attempts from the harm principle angle, we can agree that they share another common prospective. As we previously discussed, attempts may be criminalized because of their own harm to citizens, or because they carry the harm of the offense that is being attempted? The other view is by imposing punishment regardless of the connection described above.

Most authors they seem to agree that attempts have their own harmful effect, mostly because this is an advance phase in furtherance of the commission of the offense. The culpable mental state coupled with an act towards the commission of the offense is deemed sufficient to impose punishment. The result is an act or a process that tends towards the commission of an offense. If we rely to this comparison the answer suggest that like attempts, money laundering carries in itself harmful consequences and morally wrong reasons to merit imposing harsh punishments.

The other view was that money laundering harm is transferred from the previous underlying host offense. As discussed, what I called the concepts of "transferred moral blame" or "transferred harm causative" are fundamental to discuss money laundering in view of an inchoate process. Criminal attempt shares almost the same view. Professor Yaffe argues that "[u]nder the Transfer Principle, the criminality of the completed crime spreads only to attempts to perform that crime. The criminality of attempted battery derives from the criminality of battery and not from the criminality of, say, theft. The Transfer Principle supports criminalizing an attempt, then, only if a description that applies to the attempt-words that correctly describe what is attempted-is also an apt description of a kind of conduct that is legitimately criminalized thanks to the fact that it meets that description."(Yaffe:2012). This view creates an inextricably connection between criminalization of attempts because of the completed crimes, and money laundering criminalization also because of the underlying offense that generated the illegal proceeds.

\section{Conclusion}

This article tried to go to the real core of understanding the real reasons under the criminalization of money laundering by comparing this offense to other three interesting theories, with which they share common and opposite aspects and also by exploring the practical issues encountered by implementing the current legislation.

The legislator in money laundering was worried by criminalizing this offense not only because of the moral blameworthiness or the harm caused by looking in the past, for what it relates to the underlying offense and its danger, but mostly for the future fear of generating criminality and further wrongful conducts and harm.

Preventing further criminality meets perfectly with all consequentialist reasons of imposing punishment. This view of money laundering as a "harm generator" or "wrongness generator", is the most convincing about the real reasons of criminalization. It is one of the only offenses that embodies what I called a transferred and generating concept of criminalization. Without those concepts, what is left is perfectly legal and legitimate.

I think uprooting the system from the starting point, in this case by destroying the money laundering process, previous and further criminality would be destroyed. In this case money laundering is not seen as the end of a process related to another offense, but as the major cause of creating criminality, further wrongful conducts and harm by covering up previous criminality and simultaneously creating new ones.

Under this view makes perfectly sense to impose punishment under both retributivist and consequentialist theories. Money laundering should be punished not only because of the morally wrong conduct and harm caused because of the inextricably relation with the crime that generated the illegal proceeds, but mostly to prevent further criminality, because in a forward looking theory of punishment, imposing such harsh punishment serves to achieve good consequences.

Without the money, criminals will go deeper in the shadows of a dark illegal word where dirty money can be used without being laundered. This world will start to be smaller in the future and not influent for the normal world of law abiding citizens.

I am aware that this may sound like the words of a utopia because infringing the law and the desire for money is in the human nature, but our duty at the end is making this world a better place to live and not making it perfect. I believe that trying to minimize money laundering as much as we can would definitely help to prevent as a prophylactic measure and destroy further criminality. There are powerful reasons for doing that, and most of them I believe were discussed modestly by this article. 


\section{References}

Buchanan, Bonnie. (2004). Money laundering-a global obstacle. Research in International Business and Finance.

Hart, L., Carolyn. (2012). Money laundering. American Criminal Law Review.

Doyle, Charles. (2012). Money Laundering: An Overview of 18 U.S.C. 1956 and Related Federal Criminal Law February.

FATF, Combating Predicate Crimes Involved in Money Laundering.

Federal Money Laundering Regulation: Banking, Corporate and Securities Compliance Levy Part VI - State and International Measures,

(2014) Chapter 24, Worldwide Efforts Against Money Laundering, Explanation: Treatise § 27.02 Elements Of A Sound National Program.

Yaffe, Gideon. (2014). Criminal Attempts. Yale Law Journal.

Morris, Herbert. (1968). Persons and Punishment. The Monist Volume 52, Issue 4: Human Rights.

Hart, H., L. A. (2008). Punishment and Responsibility (Oxford eds., $2^{\text {nd }}$ ed.).

Hart, H., L. A. (1955). Are there any natural rights? The Philosophical Review, Vol 64. N0.2.

Johnson, B., James. (2005). An Examination Of New Jersey's Money Laundering Statutes. Seton Hall Legis Journal.

Richards, R., James. (1999). Transnational Criminal Organizations, Cybercrime, and Money Laundering (Harvey Cane. eds., 1st ed.).

Hasnas, John. (2012). Attempt, Preparation, and Harm: The Case of the Jealous Ex-Husband. Ohio State Journal of Criminal Law.

Myers, L., Julie. (2007). Money Laundering-Using Financial Expertise To Get The Bad Guys, Assistant Secretary of Homeland Security, U.S. Immigration and Customs Enforcement Delivered to the World Research Group Anti-Money Laundering and Fraud Prevention Conference, Arlington, Virginia.

Walker, John., Unger, Brigitte. (2009). Measuring Global Money Laundering, The Walker Gravity Model, University of Wollongong, Australia; Utrecht University School of Economics.

Scura, Kevin (2013). Money Laundering. American Criminal Law Review.

Birger, Grossfield., Laura. (2012). Money-Laundering Statutes May Implicate The Innocent Recent Third Circuit Decision Suggests There Are Limitations. Law Journal Newsletters, Volume 19, Number 5.

Chiesa, E., Luis. (2014). Substantive Criminal Law (Carolina Academic Press. eds., 1th ed).

Cuéllar, Mariano-Florentino. (2003). The Tenuos Relationship Between The Fight Against Money Laundering And The Disruption of Criminal Finance. Journal of Criminal Law \& Criminology.

Dagger, Richard. (1993). Playing Fair with Punishment, in Ethics. The University of Chicago Press, Vol. 103, No. 3.

Zimarowski, Rachel. (2010). Taking A Gamble: Money Laundering After Inted States V. Santos. West. Virginia Law Review.

Jordan, D., Sandra. (2003). Fraud And Money Laundering -- A Renewed Look At Sentencing Guidelines. No. 8 White-Collar Crime Rep.

Vaithilingam, Santha., Nair, Mahendhiran. (2009). Mapping global money laundering trends: Lessons from the pace setters. Research in International Business and Finance 23, 18-30.

Philippsohn, Steven (2001). Computers \& Security, Money Laundering on the Internet.

Comisky, M., lan., Feld. S., Lawrence., Harris, M., Steven. (2014). Tax Fraud \& Evasion Current Through 2014, Sentencing for Tax, Money-Laundering, and Currency-Reporting Offenses. Money-Laundering And Currency-Reporting Guidelines.

Adams. E., Teresa. (2000). Tacking On Money Laundering Charges To White Collar Crimes: What Did Congress Intend, And What Are The Courts Doing. Georgia State University Law Review.

Sobek, Tomáš. (2011).Good Consequences. The Lawyer Quarterly.

U.N. Financial Action Task Force. (2009). Money Laundering through the Football Sector, Report.

U.N. Financial Action Task Force. (2009). Vulnerabilities of Casinos and Gaming Sector, Report.

U.S Gov'T Accountability Office, GAO-02-670. (2002). Report of the Chairman, Permanent Subcommittee on Investigations, Committee on Governmental Affairs, U.S. Senate, Money Laundering Extent of Money Laundering through Credit Cards is Unknown.

Perkel, Walter. (2004). Money Laundering And Terrorism: Informalvalue Transfer System. American Criminal Law Review.

WestLawNext Publications, United States v Gallo 927 F2d 815 (1991).

WestLawNext Publications U.S. v. Oliveros, 275 F.3d 1299 (11th Cir. 2001).

WestLawNext Publications, United States v Campbell 977 F2d 854 (1992).

WestLawNext Publications United States v. Santos, 553 U.S. 507 (2008).

Phelps, G., William. (1994). Validity, construction, and application of 18 U.S.C.A § 1956, which criminalizes money laundering, A.L.R Federal. 